\title{
Effects of Body Weight Reduction on Plasma Leptin and Adiponectin/Leptin Ratio in Obese Patients With Type 1 Diabetes Mellitus
}

\author{
F. MUSIL ${ }^{1}$, V. BLAHA ${ }^{1}$, A. TICHA ${ }^{2}$, R. HYSPLER ${ }^{2}$, M. HALUZIK ${ }^{3}$, J. LESNA ${ }^{1}$, \\ A. SMAHELOVA ${ }^{1}$, L. SOBOTKA ${ }^{1}$
}

${ }^{1}$ Department of Metabolic Care and Gerontology, Faculty of Medicine, Charles University and University Hospital, Hradec Králové, Czech Republic, ${ }^{2}$ Department of Research and Development, University Hospital, Hradec Králové, Czech Republic, ${ }^{3}$ Third Department of Medicine, Charles University and General University Hospital, Prague, Czech Republic

Received December 19, 2013

Accepted July 21, 2014

On-line October 15, 2014

\section{Summary}

The aim of this study was to explore the changes in the adipokines leptin and adiponectin in obese patients with type 1 diabetes mellitus (T1DM) who underwent seven days of fasting and 21 days of low-calorie diet (LCD). The plasma leptin and adiponectin concentrations were measured in 14 obese patients with T1DM at baseline, immediately after 7 days of fasting, and after 21 days of LCD. 13 non-obese patients with T1DM were studied only after an overnight fasting. Bioimpedance technique was used for determination of body composition. Obese T1DM patients lost $6.0 \mathrm{~kg}(6.0 ; 6.8)$ (median, $25 \% ; 75 \%$ ) and decreased their fat tissue after fasting and LCD. Plasma leptin in obese T1DM was significantly higher than in non-obese T1DM patients: $9.10(5.06 ; 25.89)$ vs. $1.71(1.12 ; 7.08) \mu \mathrm{g} \cdot \mathrm{I}^{-1}$ and transiently decreased immediately after fasting: $3.45 \mu \mathrm{g} \cdot \mathrm{I}^{-1}$ $(1.47 ; 7.00),(P<0.05)$. Adiponectin/leptin ratio in obese T1DM was significantly lower than in non-obese T1DM patients: 0.67 $(0.57 ; 1.49)$ vs. $3.50(2.46 ; 6.30) \cdot 10^{3}$ and transiently increased immediately after fasting: $2.22(1.26 ; 3.24) \cdot 10^{3},(P<0.05)$. We conclude that obese patients with T1DM are characterized by hyperleptinemia that is reduced by prolonged fasting, but only slightly affected by low calorie diet.

\section{Key words}

Type 1 diabetes mellitus - Obesity - Fasting - Leptin • Adiponectin

\section{Corresponding author}

F. Musil, Department of Metabolic Care and Gerontology, University Hospital Hradec Králové and Medical Faculty Charles University in Hradec Králové, Sokolská 581, 50005 Hradec Králové, Czech Republic. Fax: +420495832001. E-mail: musil@fnhk.cz

\section{Introduction}

There is evidence that the prevalence of obesity in T1DM patients is growing (Libman et al. 2003). Although insulin deficiency is the main pathogenic factor in T1DM, obese subjects with T1DM can also be insulin resistant (Pambianco et al. 2007), and the pathogenesis of their micro- and macrovascular complications is now attributed partly to insulin resistance (IR) (Kilpatrick et al. 2007, Thorn et al. 2005, Orchard et al. 2003) as well as classical factors, such as metabolic control, body mass index, smoking, dyslipidemia, and hypertension. The pathophysiological link between obesity and IR remains to be elucidated, but several recent studies indicate a central role for adipose tissue and its endocrine dysfunction (Mora and Pressin 2002, Aldhahi and Hamdy 2003, Ferroni et al. 2004). Obesity is typically associated with a more proinflammatory endocrine profile of adipose tissue that contributes to the development of its metabolic complications, including IR and type 2 diabetes mellitus (Mráz et al. 2011). It is thus conceivable 
that obesity in patients with type 1 diabetes mellitus could also contribute to the development of subclinical inflammation and IR.

The adipokines leptin and adiponectin have been most extensively studied in patients with obesity and type 2 diabetes mellitus. Plasma leptin concentration increases in proportion to body fat mass, and regulates food intake and energy expenditure to maintain body fat stores (Campfield et al. 1995). Leptin is secreted into the bloodstream and reaches the brain through the bloodbrain barrier and blood-cerebrospinal fluid barrier. Leptin acts on the hypothalamus, where it induces anorexia (Elmquist et al. 1999, Housa et al. 2006, Huml et al. 2011). Hyperleptinemia, which either manifests gradually in association with age-related obesity or is generated rapidly by the consumption of energy-enriched diets, is associated with decreased brain leptin concentrations (Kalra 2011). Increased blood levels of leptin fail to reduce feeding or to be reflected in increased levels of leptin in the cerebrospinal fluid. If leptin is delivered directly into the brain, it reduces feeding, but delivery into the blood is essentially without effect (Kastin and Pan 2006). The mechanism of leptin resistance has been elucidated. The first cause of leptin resistance is impaired leptin transport across the brain-blood barrier. The second cause of leptin resistance is impaired leptin signal transduction in hypothalamic neurons (Burguera et al. 2000).

In healthy leptin-sensitive individuals, leptin inhibits insulin biosynthesis and secretion from pancreatic $\beta$-cells (Amitani et al. 2013). By contrast, insulin stimulates leptin secretion from adipose tissue (Tsai et al. 2012). Leptin stimulates hepatic gluconeogenesis and hepatic insulin sensitivity via the hepatic branch of the vagus nerve. Additionally, leptin increases glucose uptake in skeletal muscle, heart, and brown adipose tissue via the sympathetic nervous system. In leptin-resistant overweight individuals, insufficiency of leptin signaling in the hypothalamus (induced in obese subjects by hyperleptinemia) causes hyperglycemia and hyperinsulinemia (German et al. 2009).

Adiponectin is another insulin-sensitizing hormone produced by adipocytes, which has also antiinflammatory and anti-atherogenic properties. In obese subjects, plasma adiponectin levels are reduced. It has been suggested that adiponectin levels in plasma are inversely correlated with visceral adiposity (Matsuzawa et al. 2004, Nedvídková et al. 2005) and IR (Weyer et al. 2001). Mutations in the gene encoding for adiponectin are associated with type 2 diabetes mellitus and features of metabolic syndrome (MS) including hypertension, dyslipidemia, and atherosclerosis (Kondo et al. 2002). It has been reported that the adiponectin/leptin $(\mathrm{A} / \mathrm{L})$ ratio was more effective as a parameter of IR than was adiponectin or leptin alone, and was a more sensitive and reliable marker of IR than was homeostasis model assessment (HOMA)-IR in subjects without hyperglycemia, as well as in type 2 diabetes patients (Inoue et al. 2005, 2006). The $\mathrm{A} / \mathrm{L}$ ratio is low in subjects with MS, and gradually decreases according to the number of MS components, suggesting $\mathrm{A} / \mathrm{L}$ ratio as a predictive marker for MS (Jung et al. 2010).

We hypothesized that increased leptin and low $\mathrm{A} / \mathrm{L}$ ratio would be associated with IR in obese, Caucasian T1DM patients. A reduction of body weight in obese T1DM patients might be a crucial step in reducing their IR, but this is associated with a risk of hypoglycemia (Kemmer 1992). In this pilot study we aimed to characterize the clinical phenotype in obese patients with type 1 diabetes during body weight reduction with respect to changes of leptin and adiponectin concentrations and their relationship to metabolic and anthropometric parameters.

\section{Material and Methods}

\section{Subjects}

The details of the study groups and study design have been recently reported (Musil et al. 2013).

Briefly, fourteen obese, C-peptide-negative patients with T1DM were included in the study: 9 men and 5 females, aged 41.0 years $(23.0 ; 47.0)$, body mass index (BMI) $33.2 \mathrm{~kg} \cdot \mathrm{m}^{-2}(32.33 ; 33.63)$. The median glycated hemoglobin concentration was $7.4 \%(7.1 ; 8.1)$. For controls, we recruited 13 non-obese, C-peptidenegative patients with T1DM: 8 men and 5 females, aged 36.0 years $(22.5 ; 47.0)$, BMI $22.50 \mathrm{~kg} \cdot \mathrm{m}^{-2}$ (20.78; 24.13). The median glycated hemoglobin concentration was $8.9 \%(6.8 ; 10.0)$. There was no significant difference between the two groups of patients in age, gender ratio, duration of diabetes, or glycated hemoglobin.

\section{Study design}

Briefly, the patients were admitted to the diabetes ward and one day prior to the beginning of fasting, we performed a hyperinsulinemic-euglycemic clamp. After the clamp, patients fasted for 7 days. On the eighth day of the testing period, we repeated the 
hyperinsulinemic-euglycemic clamp, after which patients were placed on a standardized, low-calorie, diabetic diet containing $150 \mathrm{~g}$ of carbohydrates and a total of $5000 \mathrm{~kJ}$. Twenty-one days after the fasting period, patients were admitted to the diabetes ward again, and the third hyperinsulinemic-euglycemic clamp was performed. In the group of non-obese T1DM patients, only one hyperinsulinemic-euglycemic clamp was performed without any further intervention. In both groups of patients waist circumference was measured halfway between the ribs and iliac crest.

\section{Body composition monitor}

Bioimpedance spectroscopy (Fresenius Medical Care, Bad Homburg, Germany) was used to determine body composition. Total body fat mass $(\mathrm{kg})$, relative fat mass (\%), lean tissue mass $(\mathrm{kg})$, relative lean tissue mass $(\%)$, and fat tissue index - adipose tissue mass $\cdot$ height $^{-2}$ $\left(\mathrm{kg} \cdot \mathrm{m}^{-2}\right)$ - were measured.

\section{Hyperinsulinemic-euglycemic clamp}

All studies were performed after an 8 to $10-\mathrm{h}$ overnight fast. The two-step hyperinsulinemiceuglycemic clamp, lasting $6 \mathrm{~h}$ (period 1: 0 to $120 \mathrm{~min}$; period 2: 120 to $360 \mathrm{~min}$ ) was conducted as previously described (DeFronzo et al. 1979). Insulin action was estimated as glucose disposal (M) calculated between 320 and $360 \mathrm{~min}$. IR was calculated as $I R=1 / \mathrm{M}$.

\section{Analytical methods}

Free fatty acids were analyzed with a FFA-HR kit (Wako chemicals GmbH, Neuss, Germany) using a UV-VIS spectrophotometer (Shimadzu Pharma Spec 1700 UV Probe, Kyoto, Japan). Plasma leptin and adiponectin were analyzed with a Bio-Rad Luminex system (Millepore, Billerica, Massachusetts, United States). We analyzed plasma leptin concentration at $360 \mathrm{~min}$ of hyperinsulinemic-euglycemic clamp to evaluate the effect of hyperinsulinemia on plasma leptin concentration.

\section{Statistical methods}

The numerical data were tested according to distribution. Mann-Whitney test was used to assess the differences between obese T1DM patients vs. non-obese T1DM patients, and Wilcoxon test for the evaluation of differences between the individual phases of observation of obese T1DM patients. For correlation analysis, Spearman's correlation coefficient and the associated p- value were calculated. Statistical significance was determined based on a probability level of less than 0.05 . The statistical evaluation was performed using SigmaStat (Systat Software, Chicago IL, USA).

All data are expressed as median (lower quartile, upper quartile).

\section{Results}

Clinical and biochemical characteristics of the obese T1DM and non-obese T1DM patients are summarized in Table 1. All obese T1DM patients tolerated the period of weight reduction: they lost $6.0 \mathrm{~kg}$ $(6.0 ; 6.8)$ of body weight (median, $25 \% ; 75 \%$ ) and $7.0 \mathrm{~cm}(4.4 ; 10.0)$ in waist circumference after fasting and maintained this reduction in body weight and waist circumference after 21 days on the low-calorie diet. There was a significant decrease in body fat immediately after fasting and after 21 days on the low calorie diet in obese T1DM patients $(p<0.05)$, as measured by bioimpedance spectroscopy. Insulin resistance as estimated by $1 / \mathrm{M}$ during hyperinsulinemic-euglycemic clamp was significantly increased in obese T1DM patients compared to non-obese T1DM subjects $(p<0.05$ ) (Musil et al. 2013). Plasma leptin concentration in obese T1DM was significantly higher than in non-obese T1DM patients and transiently decreased immediately after fasting $(p<0.05)$. Plasma leptin concentration during hyperinsulinemiceuglycemic clamp significantly increased in obese T1DM $(p<0.001)$ and in non-obese T1DM $(p<0.05) . \mathrm{A} / \mathrm{L}$ ratio in obese T1DM was significantly lower than in non-obese T1DM patients and transiently increased immediately after fasting $(p<0.05)$.

Significant positive Spearman's correlation was found in obese T1DM subjects before fasting and in nonobese T1DM between leptin and body fat, relative body fat, and fat tissue index $(p<0.05)$. Significant negative Spearman's correlation was found in obese T1DM subjects before fasting and in non-obese T1DM between $\mathrm{A} / \mathrm{L}$ ratio and body weight, BMI, body fat, relative body fat, and fat tissue index $(p<0.05)$. Significant negative Spearman's correlation was found in obese T1DM subjects before fasting and in non-obese T1DM between adiponectin and IR $(1 / \mathrm{M})(p<0.05)$ (Table 2$)$.

\section{Discussion}

This study provides a comparative analysis of the clinical phenotype of type 1 diabetic subjects with 
Table 1. Characteristics of the obese T1DM and non-obese T1DM patients.

\begin{tabular}{|c|c|c|c|c|}
\hline $\begin{array}{l}\text { Obese T1DM } \\
(n=14)\end{array}$ & Before fasting & After fasting & $\begin{array}{l}21 \text { days after low calorie } \\
\text { diet }\end{array}$ & $\begin{array}{l}\text { Non-obese T1DM } \\
(n=13)\end{array}$ \\
\hline Body mass index & 33.2 & 31.4 & 31.4 & 22.50 \\
\hline$\left(k g \cdot m^{-2}\right)$ & $(32.33 ; 33.63) \#$ & $(29.9 ; 31.6) * *$ & $(29.0 ; 31.2) * *$ & $(20.78 ; 24.13)$ \\
\hline \multirow[t]{2}{*}{ Body weight $(\mathrm{kg})$} & 98.5 & 92.5 & 91.5 & 71.0 \\
\hline & $(93.8 ; 101.1) \#$ & $(88.5 ; 95.1) * *$ & $(86.0 ; 95.8) * *$ & $(61.5 ; 76.5)$ \\
\hline \multirow[t]{2}{*}{ Waist circumference $(\mathrm{cm})$} & 108.0 & 100.0 & 101.0 & 80.0 \\
\hline & $(103.3 ; 110.5) \#$ & $(90.0 ; 102.0) * *$ & $(93.5 ; 103.0) * *$ & $(73.8 ; 88.3)$ \\
\hline \multirow[t]{2}{*}{ Body fat $(\mathrm{kg})$} & 36.0 & 32.2 & 32.5 & 13.6 \\
\hline & $(33.3 ; 41.7) \#$ & $(30.3 ; 35.6) *$ & $(29.1 ; 36.1) *$ & $(9.0 ; 18.0)$ \\
\hline \multirow[t]{2}{*}{ Relative body fat (\%) } & 36.1 & 35.3 & 34.4 & 20.9 \\
\hline & $(33.3 ; 39.4) \#$ & $(31.6 ; 39.7)$ & $(31.8 ; 38.1)$ & $(12.7 ; 27.7)$ \\
\hline \multirow[t]{2}{*}{ Fat tissue index $\left(\mathrm{kg} \cdot \mathrm{m}^{-2}\right)$} & 16.1 & 13.8 & 14.4 & 5.9 \\
\hline & $(14.7 ; 17.7) \#$ & $(13.0 ; 16.7) *$ & $(13.1 ; 16.2) *$ & $(3.70 ; 9.30)$ \\
\hline Glucose disposal (M) & 9.50 & 6.68 & 9.65 & 12.1 \\
\hline$\left(m g \min ^{-1} \mathrm{~kg}^{-1}\right)$ & $(9.04 ; 10.3) \#$ & $(6.35 ; 7.69) * *$ & $(8.63 ; 10.1)$ & $(10.7 ; 13.1)$ \\
\hline 1/Glucose disposal (M) & 0.11 & 0.15 & 0.10 & 0.08 \\
\hline$\left(\mathrm{mg}^{-1} \cdot \min \cdot \mathrm{kg}\right)$ & $(0.10 ; 0.11) \#$ & $(0.13 ; 0.16) * *$ & $(0.10 ; 0.11)$ & $(0.08 ; 0.09)$ \\
\hline \multirow[t]{2}{*}{$F F A\left(m m o l \cdot l^{-1}\right)$} & 0.46 & 0.99 & 0.4 & 0.27 \\
\hline & $(0.34 ; 0.58) \#$ & $(0.78 ; 1.36) *$ & $(0.36 ; 0.68)$ & $(0.17 ; 0.61)$ \\
\hline \multirow[t]{2}{*}{ Leptin $\left(u g \cdot l^{-1}\right)$} & 9.10 & 3.45 & 9.55 & 1.71 \\
\hline & $(5.06 ; 25.89) \#$ & $(1.47 ; 7.00) *$ & $(6.06 ; 16.86)$ & $(1.12 ; 7.08)$ \\
\hline Leptin $\left(\mu g \cdot l^{-1}\right)$ in $360 \mathrm{~min}$ & 22.7 & 12.4 & 20.6 & 4.15 \\
\hline of clamp procedure & $(15.3 ; 39.2)^{\mathrm{a}}$ & $(3.91 ; 16.4)^{\mathrm{a}}$ & $(13.3 ; 27.9)^{\mathrm{a}}$ & $(2.20 ; 13.0)^{b}$ \\
\hline Adiponectin & 7.98 & 6.49 & 7.65 & 11.45 \\
\hline$\left(m g \cdot l^{-1}\right)$ & $(5.82 ; 11.36)$ & $(5.25 ; 8.51)$ & $(5.66 ; 9.76)$ & $(6.85 ; 15.45)$ \\
\hline Ratio adiponectin/leptin & 0.67 & 2.22 & 0.73 & 3.50 \\
\hline$\cdot 10^{3}$ & $(0.57 ; 1.49) \#$ & $(1.26 ; 3.24) *$ & $(0.49 ; 0.83)$ & $(2.46 ; 6.30)$ \\
\hline
\end{tabular}

** $p<0.001$, before fasting vs. the indicated time in obese T1DM subjects (Wilcoxon test). $* p<0.05$, before fasting vs. the indicated time in obese T1DM subjects (Wilcoxon test). \# $p<0.05$ between obese T1DM subjects before fasting and non-obese T1DM (MannWhitney test). ${ }^{\mathrm{a}} p<0.001$, leptin before clamp procedure vs. leptin at the indicated time of clamp procedure (Wilcoxon test). ${ }^{\mathrm{b}} p<0.05$, leptin before clamp procedure vs. leptin at the indicated time of clamp procedure (Wilcoxon test). Data in Table 1 are expressed as median (lower quartile, upper quartile).

regard to obesity, leptin and adiponectin concentrations, and insulin resistance. Our study confirms that type 1 diabetes in obese subjects shares many characteristics with previous data in insulin-resistant obese individuals with type 2 diabetes or metabolic syndrome, but retains differences fundamental to their respective pathophysiologies. In spite of having a different type of diabetes, obese T1DM patients with increased BMI, body fat and waist circumference share features of IR with patients with type 2 diabetes. The obese patients with T1DM in our study were characterized by hyperleptinemia. Plasma leptin was identified as having a positive association with adiposity and IR (Mente et al.
2010). The T1DM patients in our study showed significant positive correlation between leptin and BMI and adiposity. During the study, leptin concentrations transiently fell after seven days of fasting. In previous studies in obese T2DM, the reduction of fat mass occurring during weight loss resulted in decreased leptin concentrations (Monzillo et al. 2003, Pasarica et al. 2009, Mráz et al. 2011, Urbanavičius et al. 2013, Palikhe et al. 2014). After weight loss, individuals maintaining a reduced weight have reduced energy expenditure (Rosenbaum et al. 2008, Tremblay and Chaput 2009), decreased sympathetic nervous system tone, lower circulating concentrations of leptin, thyroxine and 
Table 2. Spearman's correlation analysis in obese T1DM subjects before fasting and non-obese T1DM.

\begin{tabular}{lcc}
\hline & Correlation coefficient & P value \\
\hline Leptin $\left(\mu \mathrm{g} \cdot l^{-1}\right)$ and Fat tissue index $\left(\mathrm{kg} \cdot \mathrm{m}^{-2}\right)$ & 0.52 & 0.007 \\
Leptin $\left(\mu \mathrm{g} \cdot l^{-1}\right)$ and Body fat $(\mathrm{kg})$ & 0.51 & 0.008 \\
Leptin $\left(\mu \mathrm{g} \cdot l^{-1}\right)$ and Relative body fat $(\%)$ & 0.48 & 0.013 \\
Adiponectin $\left(\mathrm{mg} \cdot l^{-1}\right)$ and $1 / \mathrm{M}\left(\mathrm{mg}^{-1} \cdot \mathrm{min} \cdot \mathrm{kg}\right)$ & -0.40 & 0.044 \\
Ratio adiponectin/leptin $\cdot 10^{3}$ and Body mass index $\left(\mathrm{kg} \cdot \mathrm{m}^{-2}\right)$ & -0.39 & 0.049 \\
Ratio adiponectin/leptin and Body weight $(\mathrm{kg})$ & -0.46 & 0.020 \\
Ratio adiponectin/leptin $\cdot 10^{3}$ and Fat tissue index $\left(\mathrm{kg} \cdot \mathrm{m}^{-2}\right)$ & -0.61 & 0.001 \\
Ratio adiponectin/leptin and Body fat $(\mathrm{kg})$ & -0.62 & $<0.001$ \\
Ratio adiponectin/leptin and Relative body fat $(\%)$ & -0.56 & 0.002
\end{tabular}

triiodothyronine, and increased parasympathetic nervous system tone. Thus, metabolic, autonomic, and neuroendocrine systems act in conjunction to favor weight regain after otherwise successful weight loss (Rosenbaum et al. 2005, Lips et al. 2013). In previous clinical studies, most of these metabolic, autonomic, and neuroendocrine changes favoring weight gain via decreased energy expenditure were reversed by the administration of leptin to weight-reduced individuals (Farooqi et al. 1999, Rosenbaum et al. 2005, Galgani et al. 2010). In our study, plasma leptin after 21 days of low calorie diet remained high despite maintained reduced body weight in obese T1DM patients. The explanation for this difference may be the fact that the fasting itself and not the adipose mass reduction is the primary regulator of leptin levels in T1DM. This regulatory mechanism was described in a previous study with normal weight and obese volunteers (Boden et al. 1996, Mantzoros et al. 2011). The previous studies did not include T1DM patients treated by insulin. Insulin stimulates leptin secretion from adipose tissue (Tsai et al. 2012). By this mechanism, insulin treatment in obese T1DM patients during the LCD period could also contribute to hyperleptinemia. Plasma leptin concentration during hyperinsulinemic-euglycemic clamp in our study significantly increased in both groups of patients. Another explanation for hyperleptinemia after the LCD period in obese T1DM patients is the fact that the LCD did not lead to further weight loss. A reduction of body weight in obese T1DM patients is associated with a risk of hypoglycemia (Kemmer 1992). We explain the absence of further weight loss after LCD by problems in adherence to LCD amongst obese T1DM patients who were treated with insulin.

Another interesting finding from our study is the fact that serum adiponectin concentrations in obese type 1 diabetes patients did not differ from the lean control type 1 diabetes group nor were they significantly affected by the weight loss. This finding is in contrast to previous results in patients with obesity and type 2 diabetes mellitus where long-term weight loss significantly increased serum adiponectin concentrations (Pasarica et al. 2009, Urbanavičius et al. 2013, Palikhe et al. 2014). The reason for the unchanged adiponectin levels in our study may be the relatively short term duration of the study and rather modest weight loss. Several previous studies showed that moderate weight loss in the obese does not result in the elevation of adiponectin levels (Blesso et al. 2013, Mediano et al. 2013). Our study did confirm a negative association of $\mathrm{A} / \mathrm{L}$ ratio with $\mathrm{BMI}$, adiposity and IR in obese T1DM before fasting and in non-obese T1DM, as reported in previous studies (Vega and Grundy 2013), and a negative association between adiponectin and IR (Weyer et al. 2001). The high lipolytic activity during massive weight loss after seven days of fasting in our obese T1DM patients, who had IR before the weight reduction program, was associated with significant increase of FFA, which paralleled a temporary decrease in insulin sensitivity caused by the reduction of glucose oxidation. This decline in glucose oxidation reflects a metabolic adaptation to non-stress fasting and is in agreement with previous publications (Awad et al. 2009, Duška et al. 2005, Féry and Balasse 1994).

Despite bringing some novel data, our study has several limitations that need to be taken into account when interpreting the results. The major limitation of this study is the small number of patients (14 obese patients with T1DM and IR and 13 non-obese patients with T1DM). However, obese patients were investigated three times during the observation period of 30 days to obtain a 
detailed impression of the serum leptin levels during pronounced weight loss. The concentrations of leptin and adiponectin were measured up to day 30 of the experimental protocol but no longer, which might have underestimated the association between the investigated factors and IR. Additionally, we cannot exclude the presence of any genetic variations in the leptin gene associated with the concentrations of leptin, although the contribution of these variants might be small compared to other clinical features such as BMI (Becer et al. 2013, Schwenk et al. 2013).

We conclude that obese patients with type 1 diabetes mellitus are characterized by insulin resistance, hyperleptinemia and unchanged adiponectin concentrations. The combination of 7-days fasting with 3weeks low calorie diet did not significantly affect serum leptin or adiponectin concentrations despite a significant weight loss, suggesting that mechanisms other than modulation of endocrine function of adipose tissue might be involved in the adaptation of metabolism to body weight reduction.

\section{Conflict of Interest}

There is no conflict of interest.

\section{Acknowledgements}

This work was supported by research project IGA No. NT/12287-5 from the Ministry of Health of the Czech Republic, MH-CZ - DRO (UHHK, 00179906) and PRVOUK P37/12 from the Medical Faculty Charles University in Hradec Kralove, Czech Republic.

\section{References}

ALDHAHI W, HAMDY O: Adipokines, inflammation, and the endothelium in diabetes. Curr Diab Rep 3: 293-298, 2003.

AMITANI M, ASAKAWA A, AMITANI H, INUI A: The role of leptin in the control of insulin-glucose axis. Front Neurosci 7: 51, 2013.

AWAD S, CONSTANTIN-TEODOSIU D, MACDONALD IA, LOBO DN: Short-term starvation and mitochondrial dysfunction - a possible mechanism leasing to postoperative insulin resistance. Clin Nutr 28: 497-509, 2009.

BECER E, MEHMETÇIK G, BAREKE H, SERAKINCI N: Association of leptin receptor gene Q223R polymorphism on lipid profiles in comparison study between obese and non-obese subjects. Gene 15: 16-20, 2013.

BLESSO CN, ANDERSEN CJ, BARONA J, VOLK B, VOLEK JS, FERNANDEZ ML: Effects of carbohydrate restriction and dietary cholesterol provided by eggs on clinical risk factors in metabolic syndrome. $J$ Clin Lipidol 7: 463-471, 2013.

BODEN G, CHEN X, MOZZOLI M, RYAN I: Effect of fasting on serum leptin in normal human subjects. $J$ Clin Endocrinol Metab 81: 3419-3423, 1996.

BURGUERA B, COUCE ME, CURRAN GL, JENSEN MD, LLOYD RV, CLEARY MP, PODUSLO JF: Obesity is associated with a decreased leptin transport across the blood-brain barrier in rats. Diabetes 49: 1219-1223, 2000.

CAMPFIELD LA, SMITH FJ, GUISEZ Y, DEVOS R, BURN P: Recombinant mouse OB protein: evidence for a peripheral signal linking adiposity and central neural networks. Science 269: 546-549, 1995.

DEFRONZO RA, TOBIN JD, ANDRES R: Glucose clamp technique: a method for quantifying insulin secretion and resistance. Am J Physiol 237: E214-E223, 1979.

DUŠKA F, ANDĚL M, KUBĚNA A, MACDONALD IA: Effects of acute starvation on insulin resistance in obese patients with and without type 2 diabetes mellitus. Clin Nutr 24: 1056-1064, 2005.

ELMQUIST JK, ELIAS CF, SAPER CB: From lesions to leptin: hypothalamic control of food intake and body weight. Neuron 22: 221-232, 1999.

FAROOQI IS, JEBB S, LANGMACK G, LAWRENCE E, CHEETHAM CH, PRENTICE AM, HUGHES IA, MCCAMISH MA, O'RAHILLY S: Effects of recombinant leptin therapy in a child with congenital leptin deficiency. N Engl J Med 341: 879-884, 1999.

FERRONI P, BASILI S, FALCO A, DAVI G: Inflammation, insulin resistance and obesity. Curr Atheroscler Rep 6: 424-431, 2004. 
FÉRY F, BALASSE EO: Glucose metabolism during the starved-to-fed transition in obese patients with NIDDM. Diabetes 43: 1418-1425, 1994.

GALGANI JE, GREENWAY FL, CAGLAYAN S, WONG ML, LICINIO J, RAVUSSIN E: Leptin replacement prevents weight loss-induced metabolic adaptation in congenital leptin-deficient patients. J Clin Endocrinol Metab 95: 851-855, 2010.

GERMAN J, KIM F, SCHWARTZ GJ, HAVEL PJ, RHODES CJ, SCHWARTZ MW, MORTON GJ: Hypothalamic leptin signaling regulates hepatic insulin sensitivity via a neurocircuit involving the vagus nerve. Endocrinology 150: 4502-4511, 2009.

HOUSA D, HOUSOVÁ J, VERNEROVÁ Z, HALUZÍK M: Adipocytokines and cancer. Physiol Res 55: 233-244, 2006.

HUML M, KOBR J, SIALA K, VARVAŘOVSKÁ J, POMAHAČOVÁ R, KARLÍKOVÁ M, SÝKORA J: Gut peptide hormones and pediatric type 1 diabetes mellitus. Physiol Res 60: 647-658, 2011.

INOUE M, MAEHATA E, YANO M, TANIYAMA M, SUZUKI S: Correlation between the adiponectin-leptin ratio and parameters of insulin resistance in patients with type 2 diabetes. Metabolism 54: 281-286, 2005.

INOUE M, YANO M, YAMAKADO M, MAEHATA E, SUZUKI S: Relationship between the adiponectin-leptin ratio and parameters of insulin resistance in subjects without hyperglycemia. Metabolism 55: 1248-1254, 2006.

JUNG CH, RHEE EJ, CHOI JH, BAE JC, YOO SH, KIM WJ, PARK CY, MOK JO, KIM CH, LEE WY, OH KW, PARK SW, KIM SW: The relationship of adiponectin/leptin ratio with homeostasis model assessment insulin resistance index and metabolic syndrome in apparently healthy Korean male adults. Korean Diabetes $J$ 34: 237-243, 2010.

KALRA SP: Pivotal role of leptin-hypothalamus signaling in the etiology of diabetes uncovered by gene therapy: a new therapeutic intervention? Gene Ther 18: 319-325, 2011.

KASTIN AJ, PAN W: Intranasal leptin: blood-brain barrier bypass (BBBB) for obesity? Endocrinology 147: 20862087, 2006.

KEMMER FW: Prevention of hypoglycemia during exercise in type I diabetes. Diabetes Care 15: 1732-1735, 1992.

KILPATRICK ES, RIGBY AS, ATKIN SL: Insulin resistance, the metabolic syndrome, and complication risk in type 1 diabetes: "double diabetes" in the diabetes control and complications trial. Diabetes Care 30: 707-712, 2007.

KONDO H, SHIMOMURA L, MATSUKAWA Y, KUMADA M, TAKAHASHI M, MATSUDA M, OUCHI N, KIHARA S, KAWAMOTO T, SUMITSUJI S, FUNAHASHI T, MATSUZAWA Y: Association of adiponectin mutation with type 2 diabetes: a candidate gene for the insulin resistance syndrome. Diabetes 51: 2325-2328, 2002.

LIBMAN IM, PIETROPAOLO M, ARSLANIAN SA, LAPORTE RE, BECKER DJ: Changing prevalence of overweight children and adolescents at onset of insulin-treated diabetes. Diabetes Care 26: 2871-2875, 2003.

LIPS MA, PIJL H, VAN KLINKEN JB, DE GROOT GH, JANSSEN IM, VAN RAMSHORST B, VAN WAGENSVELD BA, SWANK DJ, VAN DIELEN F, SMIT JW: Roux-en-Y gastric bypass and calorie restriction induce comparable time-dependent effects on thyroid hormone function tests in obese female subjects. Eur $J$ Endocrinol 169: 339-347, 2013.

MANTZOROS CS, MAGKOS F, BRINKOETTER M, SIENKIEWICZ E, DARDENO TA, KIM SY, HAMNVIK OP, KONIARIS A: Leptin in human physiology and pathophysiology. Am J Physiol 301: E567-E584, 2011.

MATSUZAWA Y, FUNAHASHI T, KIHARA S, SHIMOMURA I: Adiponectin and metabolic syndrome. Arterioscler Thromb Vasc Biol 24: 29-33, 2004.

MEDIANO MF, NEVES FA, CUNHA AC, DE SOUZA EP, MOURA AS, SICHIERI R: Changes in body weight, Creactive protein, and total adiponectin in non-obese women after 12 months of a small-volume, home-based exercise program. Clinics (Sao Paulo) 68: 1121-1127, 2013.

MENTE A, RAZAK F, BLANKENBERG S, VUKSAN V, DAVIS AD, MILLER R, TEO K, GERSTEIN H, SHARMA AM, YUSUF S, ANAND SS: Ethnic variation in adiponectin and leptin levels and their association with adiposity and insulin resistance. Diabetes Care 33: 1629-1634, 2010.

MONZILLO LU, HAMDY O, HORTON ES, LEDBURY S, MULLOOLY C, JAREMA C, PORTER S, OVALLE K, MOUSSA A, MANTZOROS CS: Effect of lifestyle modification on adipokine levels in obese subjects with insulin resistance. Obes Res 11: 1048-1054, 2003. 
MORA S, PRESSIN JE: An adipocentric view of signalling and intracellular trafficking. Diabetes Metab Res Rev 18: 345-356, 2002.

MRAZ M, LACINOVA Z, DRAPALOVA J, HALUZIKOVA D, HORINEK A, MATOULEK M, TRACHTA P, KAVALKOVA P, SVACINA S, HALUZIK M: The effect of very-low-calorie diet on mRNA expression of inflammation-related genes in subcutaneous adipose tissue and peripheral monocytes of obese patients with type 2 diabetes mellitus. J Clin Endocrinol Metab 96: 606-613, 2011.

MUSIL F, ŠMAHELOVÁ A, BLÁHA V, HYŠPLER R, TICHÁ A, LESNÁ J, ZADÁK Z, SOBOTKA L: Effect of low calorie diet and controlled fasting on insulin sensitivity and glucose metabolism in obese patients with type 1 diabetes mellitus. Physiol Res 62: 267-276, 2013.

NEDVÍDKOVÁ J, SMITKA K, KOPSKÝ V, HAINER V: Adiponectin, an adipocyte-derived protein. Physiol Res 54: 133-140, 2005.

ORCHARD TJ, OLSON JC, ERBEY JR, WILLIAMS K, FORREST KY, SMITHLINE KINDER L, ELLIS D, BECKER DJ: Insulin resistance related factors, but not glycemia, predict coronary artery disease in type 1 diabetes: 10-year follow-up data from the Pittsburgh Epidemiology of Diabetes Complications Study. Diabetes Care 26: 1374-1379, 2003.

PALIKHE G, GUPTA R, BEHERA BN, SACHDEVA N, GANGADHAR P, BHANSALI A: Efficacy of laparoscopic sleeve gastrectomy and intensive medical management in obese patients with type 2 diabetes mellitus. Obes Surg 24: 529-535, 2014.

PAMBIANCO G, COSTACOU T, ORCHARD TJ: The prediction of major outcomes of type 1 diabetes: a 12-year prospective evaluation of three separate definitions of the metabolic syndrome and their components and estimated glucose disposal rate: the Pittsburgh Epidemiology of Diabetes Complications Study experience. Diabetes Care 30: 1248-1254, 2007.

PASARICA M, TCHOUKALOVA YD, HEILBRONN LK, FANG X, ALBU JB, KELLEY DE, SMITH SR, RAVUSSIN E; LOOK AHEAD ADIPOSE RESEARCH GROUP: Differential effect of weight loss on adipocyte size subfractions in patients with type 2 diabetes. Obesity (Silver Spring) 17: 1976-1978, 2009.

ROSENBAUM M, GOLDSMITH R, BLOOMFIELD D, MAGNANO A, WEIMER L, HEYMSFIELD S, GALLAGHER D, MAYER L, MURPHY E, LEIBEL R: Low dose leptin reverses skeletal muscle, autonomic, and neuroendocrine adaptations to maintenance of reduced weight. $J$ Clin Invest 115: 3579-3586, 2005.

ROSENBAUM M, HIRSCH J, GALLAGHER D, LEIBEL R: Long-term persistence of adaptive thermogenesis in subjects who have maintained a reduced body weight. Am J Clin Nutr 88: 906-912, 2008.

SCHWENK RW, VOGEL H, SCHÜRMANN A: Genetic and epigenetic control of metabolic health. Mol Metab 25: 337-347, 2013.

THORN LM, FORSBLOM C, FAGERUDD J, THOMAS MC, PETTERSSON-FERNHOLM K, SARAHEIMO M, WADÉN J, RÖNNBACK M, ROSENGÅRD-BÄRLUND M, BJÖRKESTEN CG, TASKINEN MR, GROOP PH: Metabolic syndrome in type 1 diabetes: association with diabetic nephropathy and glycemic control (the FinnDiane study). Diabetes Care 28: 2019-2024, 2005.

TREMBLAY A, CHAPUT JP: Adaptive reduction in thermogenesis and resistance to lose fat in obese men. Br J Nutr 102: 488-492, 2009.

TSAI M, ASAKAWA A, AMITANI H, INUI A: Stimulation of leptin secretion by insulin. Indian J Endocrinol Metab 16 (Suppl 3): S543-S548, 2012.

URBANAVIČIUS V, ABALIKŠTA T, BRIMAS G, ABRAITIENE A, GOGELIENĖ L, STRUPAS K: Comparison of changes in blood glucose, insulin resistance indices, and adipokine levels in diabetic and nondiabetic subjects with morbid obesity after laparoscopic adjustable gastric banding. Medicina (Kaunas) 49: 9-14, 2013.

VEGA GL, GRUNDY SM: Metabolic risk susceptibility in men is partially related to adiponectin/leptin ratio. $J$ Obes 2013: 409679, 2013.

WEYER C, FUNAHASHI T, TANAKA S, HOTTA K, MATSUZAWA Y, PRATLEY RE, TATARANNI PA: Hypoadiponectinemia in obesity and type 2 diabetes: close association with insulin resistance and hyperinsulinemia. J Clin Endocrinol Metab 86: 1930-1935, 2001. 